tutions allowed to launch companies on the stock market, have been reluctant to support ideas and technological expertise alone, preferring more tangible bricksand-mortar propositions. In addition, high taxes and charges discourage companies from flotation on the stock market and make equity capital more expensive than bank finance. It is estimated that this has created a DM100,000 ( $£ 25,000$ million) "equity gap". In 1984, some 600 new companies will probably be launched on the US stock exchanges, whereas in West Germany, if the present situation continues, there will probably be no more than 20 new arrivals.

The lack of venture capital, the power behind the technology transfer represented by Silicon Valley and US biotechnology, is acute in West Germany. Yet in the United States since 1970, venture capitalists in 600 firms have invested a cumulative total of more than $\$ 8,000$ million and have, in the process, created more than 600,000 jobs. Fifteen per cent of this capital has come from abroad and an optimistic estimate is that some DM 100,000 million could be available in West Germany if the right investment framework were created. Citicorp, experienced venture capitalist of the New York Citibank, is planning to invest DM420 million in Europe, including DM 140 million in West Germany.

Home-grown steps in this direction have also now become apparent. Apart from the Wagnisfinanzierungs $\mathrm{GmbH}$, founded by a grouping of 29 banks, the most significant venture fund in West Germany has been started by Siemens under the name Techno Venture. The fund is capitalized at

\section{Technical innovation Plea for UK tax-breaks}

THE British treatment of scientific research and patenting costs for taxation purposes is anomalous and may be inhibiting research and innovation in Britain, according to a report published last week by the Technical Change Centre. The report, written by a former senior economic adviser at the Inland Revenue, concludes that there is a powerful case for a more favourable tax treatment of research, which would be helpful to progressive industrial companies and would cost no more than $£ 80$ million in its first year.

The Technical Change Centre, which is supported by the Leverhulme Foundation, the Science and Engineering Research Council and the Economic and Social Research Council, produced studies on a variety of subjects, linked by the common theme of technical change. Its examination of the tax treatment of intellectual property in Britain finds that Britain gives highly favourable treatment to capital expenditure on plant and machinery compared with that on patents and know-how. As
DM130 million, of which Siemens has contributed DM20 million and DM70 million has come from within West Germany. Private groups administer other funds, a small community has launched a fund through its local savings bank and the city of Berlin has begun a DM10 million fund. Minister of Research and Technology, Dr Heinz Riesenhuber, himself a successful businessman has advocated that 0.1 per cent of institutional funds should be used as venture capital.

Dr Riesenhuber emphasizes the need to create the right framework for research, technology transfer and commercialization, rather than direct state support and direction.

In the United States last year, it is estimated that 32 per cent of venture capital funds were contributed by pension funds, 32 per cent by insurance companies and 21 per cent by industry and foundations. Other financial routes such as tax-favoured research and development partnerships also exist to channel private funds into US industrial growth points. The OTA report concludes that "the unique complementarities between established and new firms, the well-developed science base, the availability of finances and an entrepreneurial spirit have been important in giving the United States its present competitive advantage in the commercialization of biotechnology ... . the (European countries) lag behind because they generally do not promote risk-taking, either industrially or in their government policies." The CDU/FDP motion is one step towards correcting this.

Sarah Tooze

things stand, capital expenditure on patents in Britain is written off over 17 years and expenditure on know-how over 6 years. The specific proposal examined is that expenditure should be written off as it is incurred, like that on plant and machinery. This would, it is argued, restore some of the advantages once enjoyed by research that have now all but disappeared.

The report considers a number of possible objections but does not find any of them conclusive. Some, like the probable need for more civil servants in the Patent Office to cope with the likely increased number of patent applications, are dismissed as only "debating points", while others, such as the objection that companies might make increased use of patents as marketing gimmicks, are considered to be small risks.

On the positive side, it is concluded that the total cost of the scheme would be justified to the public by its immediate benefit to the more technologically progressive firms that are thought to be essential for Britain's future economic prosperity. While the cash flow of industry as a whole would not be affected to any significant degree, there would be a strong incentive to licensees to acquire patents if their costs could be written off immediately.

Tim Beardsley
China's research

\section{Call to go back to basics}

CHINA's minister in charge of the State Scientific and Technological Commission, Mr Fang Yi, has spoken out firmly in favour of basic research as the foundation of the future scientific and technological development of the country. Addressing the fifth session of the scientific council of the Chinese Academy of Sciences recently, $\mathrm{Mr}$ Fang $\mathrm{Yi}$ noted that because major technological advances will become more and more dependent on breakthroughs in basic research, "some foreign countries" will be less willing to publicize their basic research in the open literature. China should therefore pay ever more attention to fields of basic research that will "open new paths" for technological development.

Mr Fang Yi's remarks differed considerably in emphasis from other recent official statements which put greater stress on the importance of applied research for the development of the Chinese economy, although he did note that particular emphasis should be given to "those fields of basic research which could have significant effects on the long-range development of the national economy". Current guidelines specify these fields as information science and technology, biotechnology, lasers, nuclear technology, computers and marine engineering.

As far as "big science" is concerned, with its demands for "enormous human, material and financial resources", Mr Fang Yi said that China's "limited conditions" imposed a need to be selective and to carry out only a few projects "according to our capabilities". Once a project is approved, however, scientists should be left to work in peace, since basic research demands "longterm efforts" and a tranquil atmosphere in which scientists can work in a "steady and sustained manner".

Mr Fang Yi's remarks seem intended as a not-too-veiled criticism of the attitude which still pervails in China as an aftermath of the cultural revolution and which is highly critical of the value to the economy of "intellectual" work. (Cases have been reported during the past year of misguided party activists criticizing the payment of bonuses of a few hundred yen to engineers and designers whose innovations have produced a very much larger financial gain.)

At the same time, even the Chinese Academy of Sciences will not have an entirely free hand. It must, Mr Fang Yi said, "show an adequate division of work and foster close cooperation with industrial departments, universities, national defence research departments and local research centres". In the applied sector, the Academy of Sciences must carry out research "more farsightedly, sooner and more intensively" than these other bodies.

Vera Rich 